\title{
Size Dependent Competition in Centric Diatoms as a Function of Nitrogen and Silicon Availability
}

\author{
Paul D. van Ruth ${ }^{1,2}$, Jian G. Qin ${ }^{1}$, Alan J. Branford ${ }^{3}$ \\ ${ }^{1}$ School of Biological Sciences, Flinders University, Adelaide, Australia \\ ${ }^{2}$ South Australian Research and Development Institute (Aquatic Sciences), Adelaide, Australia \\ ${ }^{3}$ School of Computer Science, Engineering and Mathematics, Flinders University, Adelaide, Australia \\ Email: jian.qin@flinders.edu.au
}

Received October 12, 2011; revised December 1, 2011; accepted December 10, 2011

\begin{abstract}
Size dependent competition was examined in two marine centric diatoms, Coscinodiscus sp. and Thalassiosira rotula at various $\mathrm{NH}_{4}^{+}, \mathrm{NO}_{3}^{-}$and $\mathrm{Si}$ concentrations. The growth responses for both species to nutrient levels were evaluated using two forms of nitrogen $\left(\mathrm{NH}_{4}\right.$ and $\left.\mathrm{NO}_{3}\right)$ and silicon in both monoculture and mixed culture conditions. Under single species culture, the impact of $\mathrm{Si}$ did not depend on $\mathrm{N}$ forms for both diatoms. The increase of $\mathrm{NH}_{4}-\mathrm{N}$ enhanced the growth of Coscinodiscus, but did not affect T. rotula. When $\mathrm{NO}_{3}-\mathrm{N}$ was the nitrogen source, cell densities of both species were significantly enhanced by increasing Si concentrations, but only $T$. rotula density was affected by increasing $\mathrm{N}$ concentration. When Coscinodiscus sp. and T. rotula grew in the same culture, Coscinodiscus sp. dominated in both $\mathrm{N}$ forms. The scale of the dominance of Coscinodiscus sp. over T. rotula increased with decreasing $\mathrm{N}$ and Si concentrations. In the competition experiment, when $\mathrm{NH}_{4}^{+}$was the $\mathrm{N}$ source, both Coscinodiscus sp. and T. rotula were significantly affected by changes in $\mathrm{N}$ concentration, but only $T$. rotula was affected by $\mathrm{Si}$. When $\mathrm{NO}_{3}$ was the $\mathrm{N}$ source, neither Coscinodiscus sp. nor $T$. rotula was affected by $\mathrm{Si}$, but $T$. rotula was enhanced by $\mathrm{N}$ levels. Regardless the $\mathrm{N}$ form, the impact of Si on neither Coscinodiscus sp. nor T. rotula depended on $\mathrm{N}$ concentration. Our results indicate that large diatom species have a competitive advantage over small species, and both large and small species were sensitive to $\mathrm{NH}_{4}-\mathrm{N}$ limitation, but the small species was more sensitive to $\mathrm{NO}_{3}-\mathrm{N}$ limitation than the large species.
\end{abstract}

Keywords: Diatoms; Size-Dependence; Nutrient Competition; Nitrogen; Silica

\section{Introduction}

The paradox of plankton refers to the apparent immunity of natural phytoplankton assemblages to the principle of competitive exclusion [1]. Within natural assemblages, many species of phytoplankton are able to co-exist despite competing for relatively few limiting resources [2]. Previous studies in this area of ecology have focussed on the needs of phytoplankton in general by examining the competitive interactions occurring between phytoplankton in different taxonomic divisions [3-5]. To date, however, there has been little study of the interactions that occur within phytoplankton species that have similar resource requirements but directly compete for limiting resources. In the case of diatoms, all species require Si for growth and survival [6], but a non-limiting supply of Si alone appears to be insufficient to ensure the survival of diatom species. To adequately compete for $\mathrm{Si}$, diatoms may require sufficient $\mathrm{N}$ for the formation of $\mathrm{Si}$ transporters $[7,8]$.

Previous studies concerning competition for nutrients in diatoms have focussed on a single nutrient uptake rate for $\mathrm{N}[5,9,10]$, or for Si $[8,11,12]$. There have been few studies to simultaneously evaluate competition for both Si and N. This study attempted to understand the population dynamics of marine diatoms by examining $\mathrm{Si}$ and $\mathrm{N}$ competition in two centric diatoms of different sizes.

Diatoms will dominate phytoplankton assemblages in the presence of a sufficient supply of Si with a Si:N ratio $>$ 25:1 [4]. There has been much investigation in the past on the role of Si in regulating the outcome of competition within phytoplankton communities. However, little is known about the influence of silicon supply on nitrogen acquisition in diatoms of different size. Si is an important nutrient for diatoms in frustule formation [13]. Without a sufficient supply of $\mathrm{Si}$, frustule formation is retarded, and diatoms are unable to grow and reproduce [8].

When competing for $\mathrm{NO}_{3}^{-}$as the limiting $\mathrm{N}$ source, the ability to take up and store excess $\mathrm{NO}_{3}^{-}$for later use would constitute an immense competitive advantage, allowing larger algal species to more efficiently compete for $\mathrm{NO}_{3}^{-}$under fluctuating conditions. In a study on $\mathrm{NO}_{3}^{-}$ uptake in diatoms, Stolte and Riegman [14] observed that 
larger cells were able to take up $\mathrm{NO}_{3}^{-}$at a higher rate for a longer period of time than small cells. Thus, the ability to store $\mathrm{NO}_{3}^{-}$gives algal species with larger vacuoles a competitive advantage when competing for $\mathrm{NO}_{3}^{-}$ as the limiting $\mathrm{N}$ source under fluctuating nitrate supply. The difficulty in storing $\mathrm{NH}_{4}^{+}$gives the uptake rate, rather than the cell size, more importance in competition for a limiting source of this nutrient [5]. Hence the species with the highest uptake rate will dominate when competing for $\mathrm{NH}_{4}^{+}$as the $\mathrm{N}$ source [15].

The objective of this study was to examine the possible influence of nitrogen source and silicon availability on competition for nitrogen between two species of marine diatom. The competitive interactions between a large and a small species of centric diatoms were evaluated when different levels of $\mathrm{Si}$ and different forms $\mathrm{N}$ were presented to the algae.

\section{Methods}

\subsection{Culture Conditions}

Two centric diatoms, Coscinodiscus sp. (strain CS-342) and Thalassiosira rotula were used in this study, and were obtained from the CSIRO collection, Hobart, Australia. There were two reasons for choosing these two species. Firstly, both species were collected from Jervis Bay, NSW in 1995, and were grown at the CSIRO in similar culture conditions to those proposed for use in this study (in $\mathrm{f} / 2$ medium at $17.5^{\circ} \mathrm{C}$ ). Thus any lag phase in growth was minimised when the specimens were cultured for this experiment. The second reason was their morphology and their size relative to each other. Coscinodiscus sp., $(100 \mu \mathrm{m} \pm 2.3 \mu \mathrm{m}$ in diameter, $35 \mu \mathrm{m} \pm 0.9$ $\mu \mathrm{m}$ thick) is much larger than $T$. rotula $(20 \mu \mathrm{m} \pm 1.3 \mu \mathrm{m}$ in diameter, $13 \mu \mathrm{m} \pm 0.7 \mu \mathrm{m}$ thick). To minimise any lag phase in growth that may have occurred when the species were exposed to the different $\mathrm{N}$ sources, specimens were grown in both $\mathrm{NO}_{3}^{-}$and $\mathrm{NH}_{4}^{+}$as $\mathrm{N}$ sources. Cultures of each species for the experiments with $\mathrm{NO}_{3}^{-}$as the sole $\mathrm{N}$ source were grown in $\mathrm{f} / 2$ medium enriched with $\mathrm{Si}$ according to the CSIRO modification of the method of [16]. Cultures for the experiments with $\mathrm{NH}_{4}^{+}$as the sole $\mathrm{N}$ source grown in enriched $\mathrm{f} / 2$ with $\mathrm{N}$ provided by $\mathrm{NH}_{4} \mathrm{Cl}$. Prior to experimentation, cultures were maintained separately at $17^{\circ} \mathrm{C}-20^{\circ} \mathrm{C}$ under fluorescent light $(12: 12 \mathrm{~h}$ light:dark). All experimental work was conducted using $250 \mathrm{ml}$ polypropylene bottles, since diatoms have been reported to etch Si directly from glassware [7].

\subsection{Growth Response of a Single Species to Changes in $\mathbf{N}$ and Si Concentrations}

Two experiments were conducted on each species in monoculture to examine the effect of limited supplies of $\mathrm{Si}$ and $\mathrm{N}$ on algal growth. These experiments were de- signed to test the growth of Coscinodiscus sp. or T. rotula under various $\mathrm{N}$ and $\mathrm{Si}$ concentrations, and to confirm that each species could survive by itself in all treatment conditions, thus ensuring that any detrimental growth was due to competition, rather than conditions in the treatment that were unsuitable for growth. A $3 \times 3$ factorial experiment was used and each species was tested under three $\mathrm{N}$ levels of either $\mathrm{NH}_{4}-\mathrm{N}$ or $\mathrm{NO}_{3}-\mathrm{N}$ and three $\mathrm{Si}$ levels. Nutrient concentrations were achieved by manipulating the amount of $N$ and $\mathrm{Si}$ in the $\mathrm{f} / 2$ medium to provide different percentages of the full $\mathrm{f} / 2$ nutrient concentrations. The nutrient treatments included $0 \% \mathrm{~N}, 50 \%$ $\mathrm{N}$ and $100 \% \mathrm{~N}$, each of which was prepared with $0 \% \mathrm{Si}$ $(0 \mu \mathrm{M}), 25 \%$ Si $(142 \mu \mathrm{M})$ and 100\% Si (562 $\mu \mathrm{M})$. Thus, three $\mathrm{Si}$ levels were prepared at each $\mathrm{N}$ level, providing nine treatment combinations, with three replicates per combination. The response of each species to these treatment combinations was examined firstly with $\mathrm{NO}_{3}^{-}$as the sole $\mathrm{N}$ source at three concentrations (0, 605 and 1210 $\mu \mathrm{M} \mathrm{NO} \mathrm{NO}_{3}^{-}$), then again using $\mathrm{NH}_{4}^{+}$as the sole $\mathrm{N}$ source at three levels (0, 28 and $\left.56 \mu \mathrm{M} \mathrm{NH}_{4}^{+}\right)$.

Each culture vessel used for the monoculture experiments contained $160 \mathrm{ml}$ of media inoculated with $40 \mathrm{ml}$ of either Coscinodiscus sp. or T. rotula, with a cell density of $100 \pm 15$ cells per ml. Vessels were thoroughly swirled twice daily to re-suspend cells, and were maintained at constant temperature $\left(22^{\circ} \mathrm{C} \pm 1^{\circ} \mathrm{C}\right)$. A volume of $60 \mathrm{ml}$ of culture was replaced with fresh medium once a day (semicontinuous culture), giving a dilution rate of $0.3 \mathrm{~d}^{-1}$, which is an acceptable approximation of steady state algal growth [3,4]. Light was provided by fluorescent tubes (12:12 h light:dark). Cell numbers were measured for each species every 2 - 3 d using a palmer counting chamber and a light microscope at $100 \times$ magnification. The number of cells present in $100 \mu \mathrm{l}$ of suspension taken from a $1 \mathrm{ml}$ sample was estimated from the average of two separate counts.

\subsection{Competition between Coscinodiscus Sp. and T. rotula for $\mathrm{N}$}

Coscinodiscus sp. and T. rotula were used to examine competition for $\mathrm{N}$ with different $\mathrm{N}$ forms, and different levels of nitrogen and silicon. A $3 \times 3$ factorial experiment was conducted including three $\mathrm{N}$ levels and three $\mathrm{Si}$ levels. Nutrient concentrations were achieved by manipulating the amount of $\mathrm{N}$ and $\mathrm{Si}$ in the $\mathrm{f} / 2$ medium to provide different percentages of each nutrient, and were identical to those used in the monoculture experiments. Thus, nine combinations of $\mathrm{N}$ and $\mathrm{Si}$ were again used with three replicates. The competition response of each species to each nutrient combination was examined firstly with $\mathrm{NO}_{3}^{-}$as the sole $\mathrm{N}$ source, then again using $\mathrm{NH}_{4}^{+}$ as the sole $\mathrm{N}$ source. 
Each vessel used for the competition experiment contained $120 \mathrm{ml}$ media with $40 \mathrm{ml}$ of Coscinodiscus sp. cells, and $40 \mathrm{ml}$ of $T$. rotula cells, each with a density of 100 cells $\cdot \mathrm{ml}^{-1} \pm 18$ cells $\cdot \mathrm{ml}^{-1}$. Vessels were swirled twice daily to resuspend cells, and were maintained at constant temperature $\left(22^{\circ} \mathrm{C} \pm 1^{\circ} \mathrm{C}\right)$. A volume of $60 \mathrm{ml}$ of culture was replaced with fresh medium once a day, to give a dilution rate of $0.3 \mathrm{~d}^{-1}$. Light was provided by fluorescent tubes (12:12 h light:dark). The impact of competition was measured directly by removing a $1 \mathrm{ml}$ sample from each flask and counting species numbers using a palmer counting chamber and a light microscope at $100 \times$ magni- fication.

\subsection{Statistical Analysis}

SPSS statistical analysis software was used for all statistical tests. The effect of the different treatment combinations on cell numbers was examined for both the monoculture and mixed culture experiments via an analysis of variance using the derived variables method [17]. The results for each replicate within the treatment were averaged over time, providing a derived variable that was indicative of the overall effect of the different treatments on cell densities over the experimental period. Univariate ANOVAs were performed on derived data from the monoculture experiments, since the cell densities of the separated species were the single dependent variables in each experiment. When the two species were combined for the competition study, the cell densities of both species were dependent variables, requiring the use of a multivariate analysis of variance. Bonferroni post-hoc multiple comparisons were used to further examine the treatment effects detected in the ANOVAs. Assumptions of normality and homoscedasticity were examined prior to all statistical tests. All data were natural log transformed. In the competition experiment, a t-test was used to detect the competitive outcome between the two diatoms. The difference between the two species densities at the final time point was calculated for each treatment level, and then tested against zero. A significance level of 0.05 was used for all tests.

\section{Results}

\subsection{Growth Response of a Single Species to Changes in $\mathrm{N}$ and $\mathrm{Si}$ Levels}

When grown in $\mathrm{NH}_{4}^{+}$as the $\mathrm{N}$ source, Coscinodiscus sp. abundance remained relatively constant throughout the course of the experiment in all treatments (Figure 1). The exception was the zero $\mathrm{NH}_{4}^{+}$treatment, where the abundance declined by approximately $30 \%$ over time. Coscinodiscus sp. was significantly affected by changes in $\mathrm{NH}_{4}^{+}$level $(P<0.001$, Table 1), with the abundance increasing across all $\mathrm{NH}_{4}^{+}$treatments. Post-hoc tests re- vealed that cell density in zero $\mathrm{NH}_{4}^{+}$concentration was significantly lower than in $28 \mu \mathrm{M} \mathrm{NH} \mathrm{NH}_{4}^{+}$and $56 \mu \mathrm{M} \mathrm{NH} \mathrm{NH}_{4}^{+}$ treatments $(P=0.001)$. There was no significant differrence between cell densities in the $28 \mu \mathrm{M} \mathrm{NH} \mathrm{NH}_{4}^{+}$and 56 $\mu \mathrm{M} \mathrm{NH} \mathrm{NH}_{4}^{+}$treatments $(P>0.40)$. Cell densities of $T$. rotula decreased by approximately $50 \%$ for all treatment
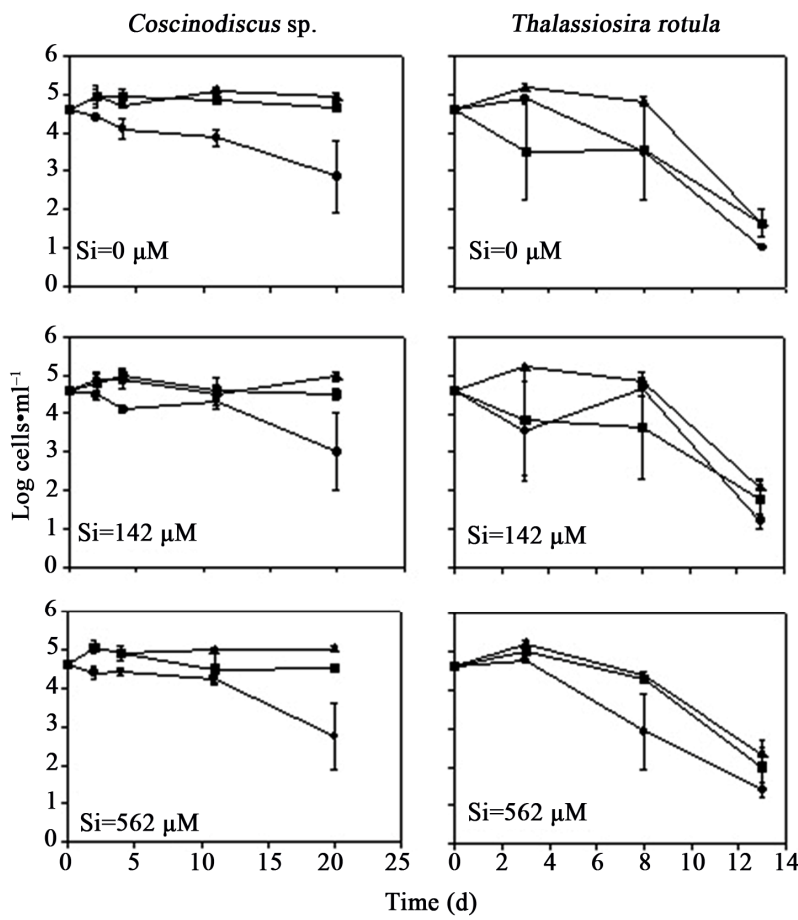

Figure 1. Growth of Coscinodiscus sp. (left) and Thalassiosira rotula (right) in monoculture over time, with three $\mathrm{Si}$ and three $\mathrm{NH}_{4}^{+}$levels: $\mathrm{Nil}(\bullet), 28 \mu \mathrm{M}(\boldsymbol{\bullet})$, and $56 \mu \mathrm{M}(\Delta)$. Values are mean \pm SE $(n=3)$. Error bars are shown only when larger than the size of the symbol.

Table 1. Univariate ANOVA results for the effects of $\mathrm{NH}_{4}^{+}$ and $\mathrm{Si}$, and $\mathrm{NO}_{3}^{-}$and $\mathrm{Si}$ on the cell densities of Coscinodiscus sp. and Thalassiosira rotula in monoculture.

\begin{tabular}{cccccccc}
\hline & \multicolumn{4}{c}{ Coscinodiscus sp. } & \multicolumn{2}{c}{ Thalassiosira rotula } \\
\cline { 2 - 8 } Source & $\mathrm{df}$ & $\mathrm{MS}$ & $F$ & $P$ & $\mathrm{MS}$ & $F$ & $P$ \\
\hline $\mathrm{NH}_{4}^{+}$ & 2 & 0.792 & 41.094 & 0.001 & 0.180 & 3.370 & 0.06 \\
$\mathrm{Si}$ & 2 & 0.006 & 0.311 & 0.74 & 0.017 & 0.319 & 0.73 \\
$\mathrm{NH}_{4}^{+} \times \mathrm{Si}$ & 4 & 0.013 & 0.687 & 0.61 & 0.021 & 0.389 & 0.81 \\
Error & 18 & 0.019 & & & 0.053 & & \\
Total & 26 & & & & & & \\
$\mathrm{NO}_{3}^{-}$ & 2 & 0.039 & 2.492 & 0.11 & 0.261 & 6.907 & 0.01 \\
$\mathrm{Si}$ & 2 & 0.29 & 18.666 & 0.001 & 0.154 & 4.082 & 0.04 \\
$\mathrm{NO}_{3}^{-} \times \mathrm{Si}$ & 4 & 0.007 & 0.473 & 0.76 & 0.016 & 0.423 & 0.79 \\
Error & 18 & 0.016 & & & 0.038 & & \\
Total & 26 & & & & & &
\end{tabular}


combinations over the duration of the study. No signifycant difference in $T$. rotula cell densities was detected between $\mathrm{NH}_{4}^{+}$treatments $(P>0.06)$. The cell densities of Coscinodiscus sp. and $T$. rotula were not significantly affected by Si concentration when $\mathrm{NH}_{4}^{+}$was the $\mathrm{N}$ source $(P>0.73)$. The impact of $\mathrm{NH}_{4}^{+}$on population abundance did not depend on Si concentration for both Coscinodiscus sp. $(P=0.61)$ and $T$. rotula $(P=0.81)$.

When $\mathrm{NO}_{3}^{-}$was the $\mathrm{N}$ source, Coscinodiscus sp. densities remained relatively unchanged for all treatment combinations over time. However, an initial decline in the cell density for both species was observed in all treatments (Figure 2). No significant difference in Coscinodiscus sp. density was detected between $\mathrm{NO}_{3}^{-}$treatments $(P=0.11$, Table 1), but cell densities were significantly enhanced by increasing Si concentration $(P=$ 0.001). Post-hoc tests showed cell densities in the zero $\mathrm{Si}$ treatment were significantly lower than densities observed in the $142 \mu \mathrm{M}$ Si and $562 \mu \mathrm{M}$ Si treatments $(P<$ $0.001)$. There was no detectable difference between the $142 \mu \mathrm{M}$ Si and $562 \mu \mathrm{M}$ Si treatments $(P=0.99)$. Cell densities of $T$. rotula also remained relatively unchanged for the duration of the monoculture experiment, with an initial decline 3 - $5 \mathrm{~d}$ after the experiment began, though not as obvious as Coscinodiscus sp. (Figure 2). Changes in both $\mathrm{NO}_{3}^{-}$and $\mathrm{Si}$ concentration had a significant effect on $T$. rotula cell density when $\mathrm{NO}_{3}^{-}$was the $\mathrm{N}$ source $(P=0.01$ and $P=0.04$, respectively; Table 1). Cell densities increased with increasing $\mathrm{NO}_{3}^{-}$and $\mathrm{Si}$ concentrations (Figure 2). Post-hoc test showed that cell numbers in the zero $\mathrm{NO}_{3}^{-}$treatment were not significantly lower than those in the $605 \mu \mathrm{M} \mathrm{NO} \mathrm{NO}_{3}^{-}$treatment $(P=$ 0.09 ), but were significantly lower than those in the1210 $\mu \mathrm{M} \mathrm{NO} \mathrm{NO}_{3}^{-}$treatment $(P=0.005)$. Cell densities in the $605 \mu \mathrm{M} \mathrm{NO} \mathrm{NO}_{3}^{-}$treatment were not significantly different from those observed in the $1210 \mu \mathrm{M} \mathrm{NO} \mathrm{NO}_{3}^{-}$treatment $(P$ $=0.65$ ). Thalassiosira rotula densities in the zero $\mathrm{Si}$ treatment were not significantly different from those in the $142 \mu \mathrm{M}$ Si treatment $(P>0.05)$, but were lower than densities in the $562 \mu \mathrm{M}$ Si treatment $(P=0.04)$. There was no significant difference in cell numbers between the $142 \mu \mathrm{M}$ Si and $562 \mu \mathrm{M}$ Si treatments $(P=0.99)$. No interactions between $\mathrm{NO}_{3}^{-}$and Si were observed for either species $(P>0.76)$.

\subsection{Competition between Two Algal Species for $\mathbf{N}$}

When grown in the same culture, Coscinodiscus sp. dominated $T$. rotula in low $\mathrm{N}$ and $\mathrm{Si}$ concentrations (Figures 3-4). When $\mathrm{NH}_{4}^{+}-\mathrm{N}$ was the $\mathrm{N}$ source, Coscinodiscus sp. density was significantly greater than the cell density of $T$. rotula by the end of the experimental period in all treatment levels except the $56 \mu \mathrm{M} \mathrm{NH_{4 } ^ { + }}$ and 562 $\mu \mathrm{M}$ Si treatment $(P=0.39$; Table 2, Figure 3). However, as the Si concentration decreased, $T$. rotula initially dominated for the first 3 days - 4 days before Coscinodiscus sp. became dominant. This initial dominance of $T$. rotula occurred in the nil Si and $142 \mu \mathrm{M}$ Si treatments for all $\mathrm{NH}_{4}^{+}$treatments and was also the case in the $28 \mu \mathrm{M} \mathrm{NH_{4 } ^ { + }}$ and $562 \mu \mathrm{M}$ Si treatments (Figure 3). When $\mathrm{NO}_{3}^{-}$was the $\mathrm{N}$ source, the cell density of Coscinodiscus sp. was significantly greater than the cell density of $T$. rotula at the end of the experiment in all treatment levels except

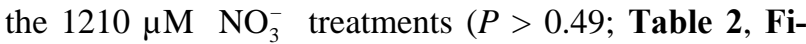
gure 4). The scale of the dominance of Coscinodiscus sp. over $T$. rotula increased with decreasing $\mathrm{NO}_{3}^{-}$and $\mathrm{Si}$ concentrations.

The outcome of competition between Coscinodiscus sp. and T. rotula for $\mathrm{N}$ differed for each $\mathrm{N}$ source. Coscinodiscus sp. was significantly affected by changes in $\mathrm{NH}_{4}^{+}$concentration, with numbers increasing across all $\mathrm{NH}_{4}^{+}$levels $(P=0.001$; Table 3, Figure 3). Post-hoc tests revealed that cell densities in the zero $\mathrm{NH}_{4}^{+}$treatment were significantly lower than those observed in the $28 \mu \mathrm{M} \mathrm{NH} \mathrm{NH}_{4}^{+}$and $56 \mu \mathrm{M} \mathrm{NH} \mathrm{NH}_{4}^{+}$treatments $(P=0.001)$. No significant difference in cell densities was detected between the $28 \mu \mathrm{M} \quad \mathrm{NH}_{4}^{+}$and $56 \mu \mathrm{M} \quad \mathrm{NH}_{4}^{+}$treatments
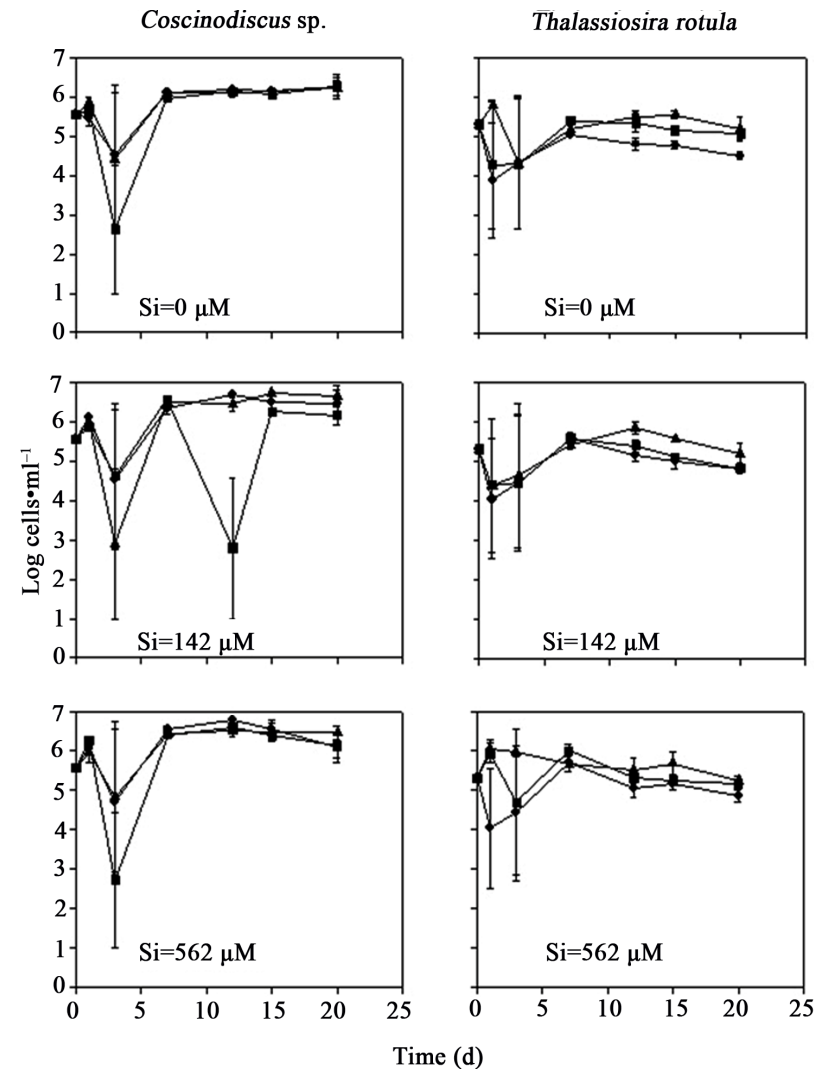

Figure 2. Growth of Coscinodiscus sp. (left) and Thalassiosira rotula (right) in monoculture over time, with three $\mathrm{Si}$ and three $\mathrm{NO}_{3}$ levels: Nil $(\bullet), 605 \mu \mathrm{M}(\bullet)$, and $1210 \mu \mathrm{M}(\Delta)$. Values are mean \pm SE $(n=3)$. Error bars are shown only when larger than the size of the symbol. 

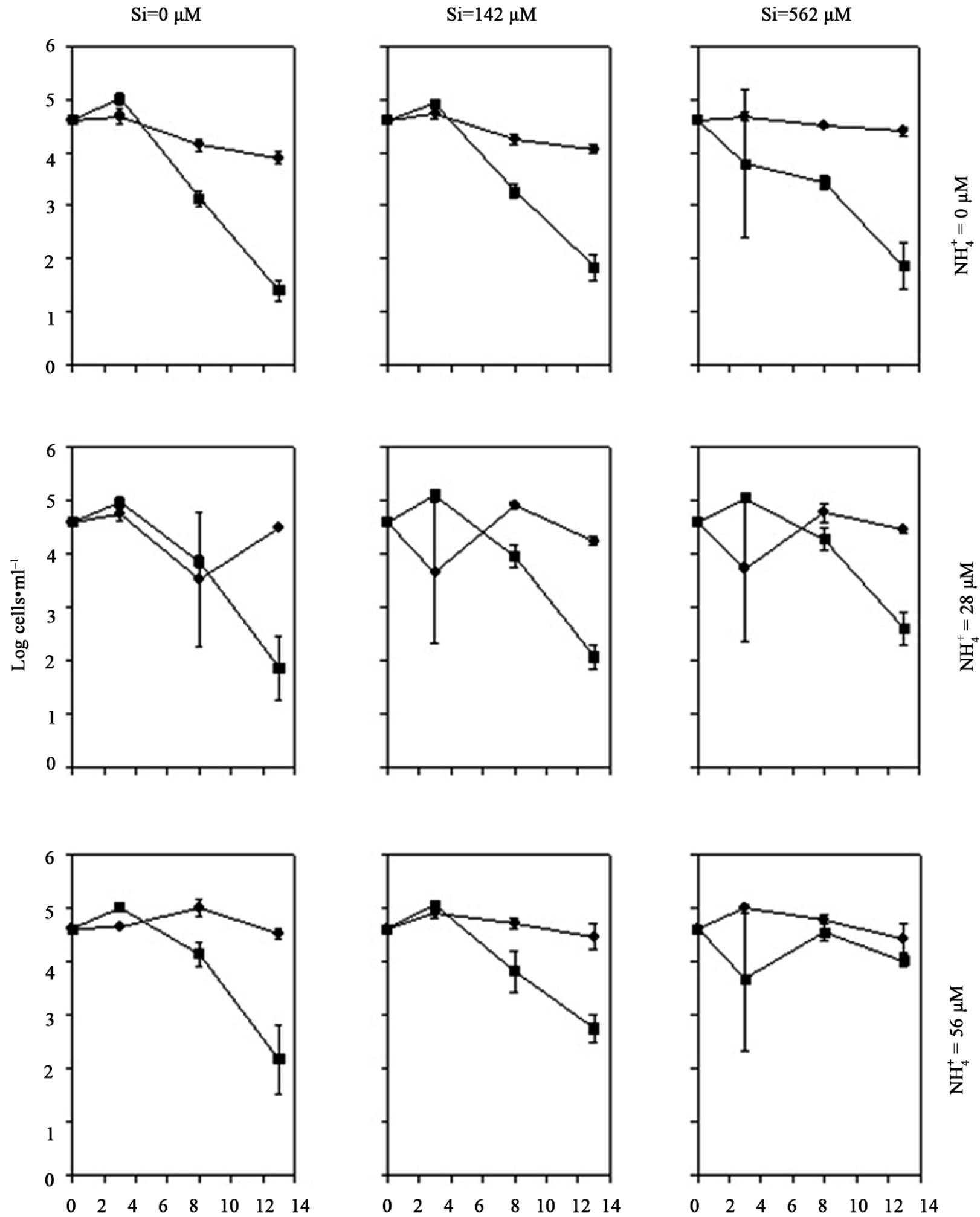

Time (d)

Figure 3. The effect of increasing $\mathrm{NH}_{4}^{+}$concentration on the cell densities of Coscinodiscus sp. (•) and Thalassiosira rotula (घ) over time in different $\mathrm{Si}$ concentrations. Values are mean \pm SE $(n=3)$. Error bars are shown only when larger than the size of the symbol. 
$\mathrm{Si}=0 \mu \mathrm{M}$
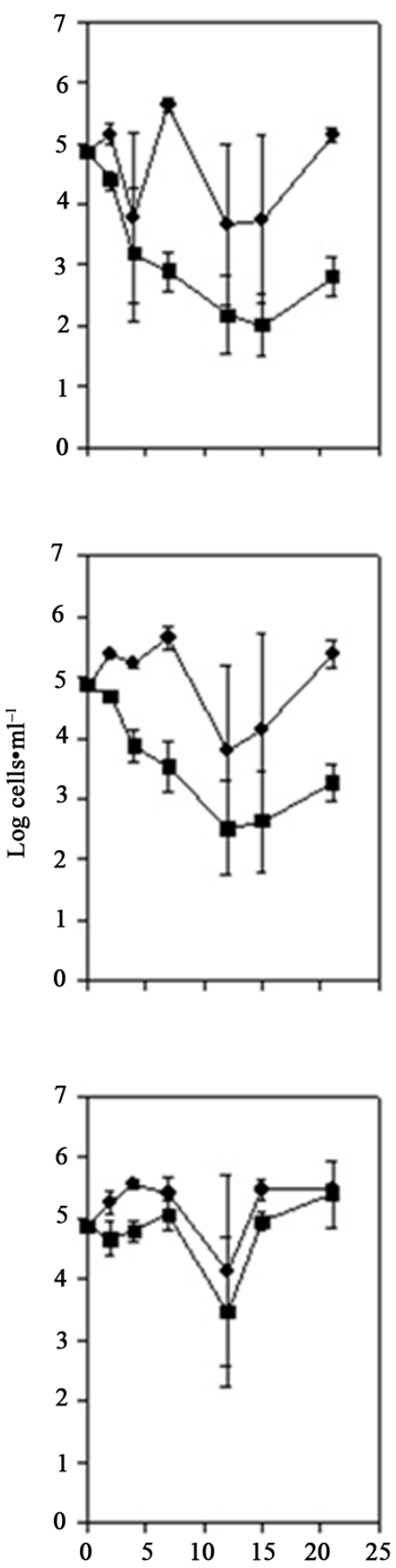

$\mathrm{Si}=142 \mu \mathrm{M}$
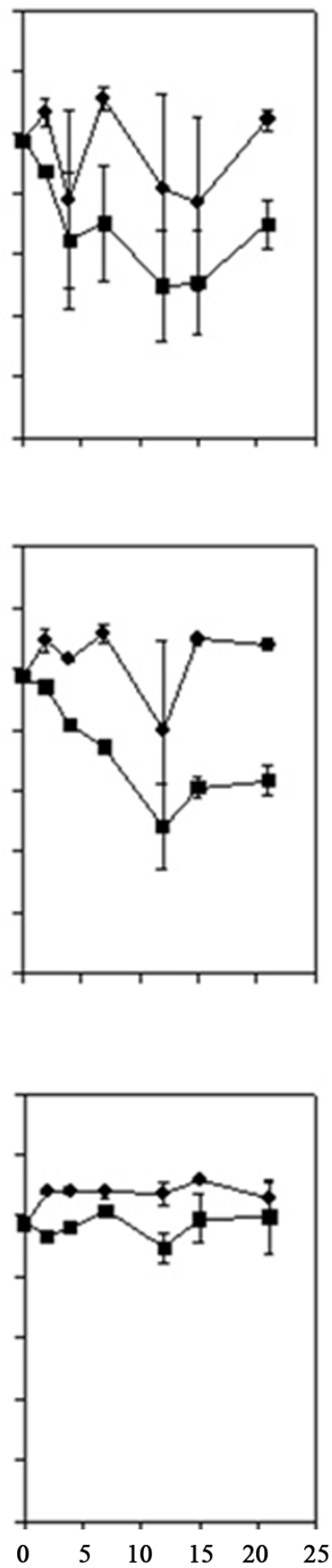

$\mathrm{Si}=562 \mu \mathrm{M}$
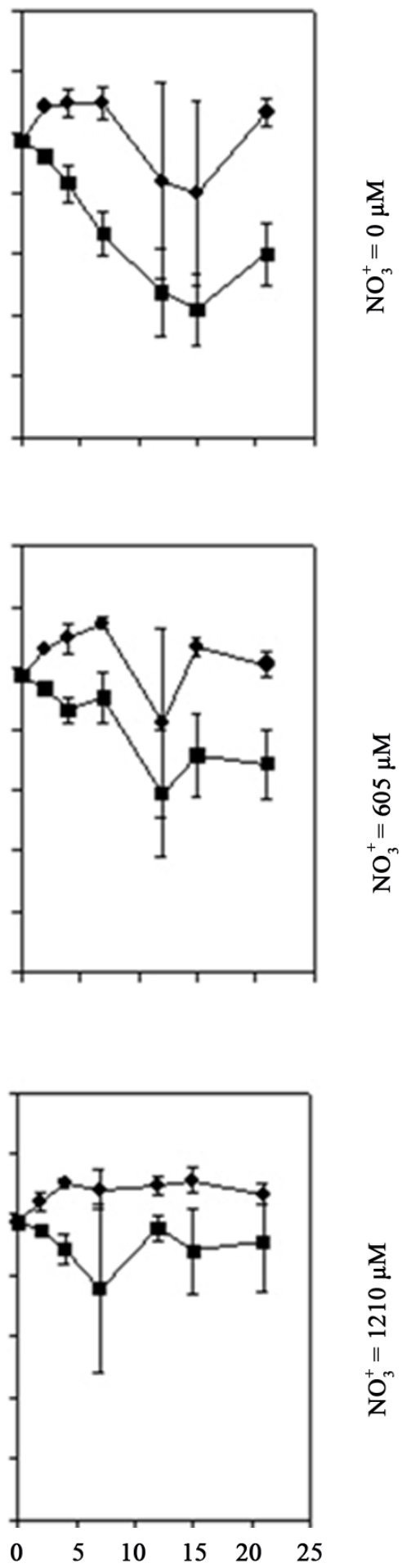

$\sum_{3}$
0

11
$0^{+m}$
$z$

Time (d)

Figure 4. The effect of increasing $\mathrm{NO}_{3}^{-}$concentration on the cell densities of Coscinodiscus sp. (•) and Thalassiosira rotula ( $\square)$ over time in different $\mathrm{Si}$ concentrations. Values are mean $\pm \mathrm{SE}(n=3)$. Error bars are shown only when larger than the size of the symbol. 
Table 2. Comparisons between Coscinodiscus sp. and Thalassiosira rotula abundances at different $\mathrm{NH}_{4}-\mathrm{N}(\mathrm{Nil}, \mathrm{Low}=$ $28 \mu \mathrm{M}$, and High $=56 \mu \mathrm{m}), \mathrm{NO}_{3}-\mathrm{N}(\mathrm{Nil}$, Low $=605 \mu \mathrm{m}$, and High $=1210 \mu \mathrm{M})$ and $\mathrm{Si}(\mathrm{Nil}$, Low $=142 \mu \mathrm{M}$, and High $=$ $562 \mu \mathrm{M})$ combinations.

\begin{tabular}{|c|c|c|c|}
\hline Treatment comparisons & $T$ & $\mathrm{df}$ & $P$ \\
\hline \multicolumn{4}{|c|}{$\mathrm{NH}_{4}-\mathrm{N}$ and $\mathrm{Si}$ combinations } \\
\hline Nil $\mathrm{NH}_{4}^{+}$vs Nil Si & 10.37 & 2 & 0.01 \\
\hline $\mathrm{Nil} \mathrm{NH}_{4}^{+}$vs Low Si & 7.25 & 2 & 0.02 \\
\hline $\mathrm{Nil} \mathrm{NH}_{4}^{+}$vs High $\mathrm{Si}$ & 6.93 & 2 & 0.02 \\
\hline Low $\mathrm{NH}_{4}^{+}$vs Nil Si & 4.53 & 2 & 0.05 \\
\hline Low $\mathrm{NH}_{4}^{+}$vs Low $\mathrm{Si}$ & 7.13 & 2 & 0.02 \\
\hline Low $\mathrm{NH}_{4}^{+}$vs High Si & 5.83 & 2 & 0.03 \\
\hline High $\mathrm{NH}_{4}^{+}$vs Nil Si & 4.22 & 2 & 0.05 \\
\hline High $\mathrm{NH}_{4}^{+}$vs Low $\mathrm{Si}$ & 4.27 & 2 & 0.05 \\
\hline High $\mathrm{NH}_{4}^{+}$vs High $\mathrm{Si}$ & 1.09 & 2 & 0.39 \\
\hline \multicolumn{4}{|c|}{$\mathrm{NO}_{3}-\mathrm{N}$ and $\mathrm{Si}$ combinations } \\
\hline $\mathrm{Nil} \mathrm{NO}_{3}$-N vs Nil Si & 7.75 & 2 & 0.02 \\
\hline $\mathrm{Nil} \mathrm{NO}_{3}-\mathrm{N}$ vs Low $\mathrm{Si}$ & 3.01 & 2 & 0.09 \\
\hline $\mathrm{Nil} \mathrm{NO}_{3}$-N vs High $\mathrm{Si}$ & 7.35 & 2 & 0.02 \\
\hline Low $\mathrm{NO}_{3}-\mathrm{N}$ vs Nil Si & 24.49 & 2 & 0.002 \\
\hline Low $\mathrm{NO}_{3}$-N vs Low $\mathrm{Si}$ & 7.11 & 2 & 0.02 \\
\hline Low $\mathrm{NO}_{3}-\mathrm{N}$ vs High $\mathrm{Si}$ & 2.65 & 2 & 0.10 \\
\hline High $\mathrm{NO}_{3}-\mathrm{N}$ vs Nil Si & 0.16 & 2 & 0.89 \\
\hline High $\mathrm{NO}_{3}-\mathrm{N}$ vs Low $\mathrm{Si}$ & 0.46 & 2 & 0.69 \\
\hline High $\mathrm{NO}_{3}-\mathrm{N}$ vs High $\mathrm{Si}$ & 0.84 & 2 & 0.49 \\
\hline
\end{tabular}

Table 3. Multivariate ANOVA results for the effects of $\mathrm{NH}_{4}^{+}$and $\mathrm{Si}$, and $\mathrm{NO}_{3}^{-}$and $\mathrm{Si}$ on the cell densities of Coscinodiscus sp. and Thalassiosira rotula in competition.

\begin{tabular}{cccccccc}
\hline & \multicolumn{4}{c}{ Coscinodiscus sp. } & \multicolumn{2}{c}{ Thalassiosira rotula } \\
\hline Source & df & MS & $F$ & $P$ & MS & $F$ & $P$ \\
\hline $\mathrm{NH}_{4}^{+}$ & 2 & 0.183 & 21.681 & 0.001 & 0.089 & 9.531 & 0.002 \\
$\mathrm{Si}$ & 2 & 0.020 & 2.310 & 0.13 & 0.040 & 4.324 & 0.03 \\
$\mathrm{NH}_{4}^{+} \times \mathrm{Si}$ & 4 & 0.004 & 0.496 & 0.74 & 0.004 & 0.411 & 0.80 \\
Error & 18 & 0.008 & & & 0.009 & & \\
$\mathrm{Total}$ & 26 & & & & & & \\
$\mathrm{NO}_{3}^{-}$ & 2 & 0.016 & 0.469 & 0.63 & 1.681 & 22.080 & 0.001 \\
$\mathrm{Si}$ & 2 & 0.009 & 0.272 & 0.77 & 0.003 & 0.035 & 0.97 \\
$\mathrm{NO}_{3}^{-} \times \mathrm{Si}$ & 4 & 0.012 & 0.358 & 0.84 & 0.081 & 1.059 & 0.41 \\
Error & 18 & 0.035 & & & 0.076 & & \\
Total & 26 & & & & & & \\
\hline
\end{tabular}

$(P=0.99)$. Coscinodiscus sp. cell densities were not sig$\mathrm{NH}_{4}^{+}-\mathrm{N}$ was the $\mathrm{N}$ source $(P=0.13$; Table 3, Figure 3). In contrast to Coscinodiscus sp., $T$. rotula densities in all treatment combinations decreased by approximately 50\% over the course of the experiment, with the exception of the $56 \mu \mathrm{M} \mathrm{NH} \mathrm{NH}_{4}^{+}$and $562 \mu \mathrm{M}$ Si combinations in which numbers declined by approximately 10\% (Figure 3). Changes in $\mathrm{NH}_{4}^{+}$concentration had a significant impact on $T$. rotula cell numbers ( $P=0.002$; Table 3$)$. Thalassiosira rotula abundance increased with increasing $\mathrm{NH}_{4}^{+}$concentration (Figure 3). Post-hoc tests revealed that cell densities in the nil $\mathrm{NH}_{4}^{+}$treatment were significantly lower than those in the $28 \mu \mathrm{M} \mathrm{NH} \mathrm{NH}_{4}^{+}$treatment $(P=$ $0.02)$, and the $56 \mu \mathrm{M} \mathrm{NH} \mathrm{NH}_{4}^{+}$treatment $(P=0.001)$. No significant difference in cell densities was detected between the $28 \mu \mathrm{M} \mathrm{NH} \mathrm{NH}_{4}^{+}$and the $56 \mu \mathrm{M} \mathrm{NH} \mathrm{NH}_{4}^{+}$treatments $(P=0.71)$. Cell densities of $T$. rotula were also signifycantly enhanced by increasing $\mathrm{Si}$ concentrations $(P=$ 0.03; Table 3, Figure 3). Post-hoc tests revealed that no significant difference in cell numbers was detected between the nil Si and $142 \mu \mathrm{M}$ Si treatments $(P=0.99)$. However, cell numbers in the zero Si treatment were significantly lower than those observed in the $562 \mu \mathrm{M} \mathrm{Si}$ treatments $(P=0.04)$. There was no significant difference in cell densities between the $142 \mu \mathrm{M}$ Si and $562 \mu \mathrm{M}$ Si treatments $(P=0.10)$. Interactions between $\mathrm{NH}_{4}^{+}$and Si levels were not detected for either species $(P>0.74)$.

When examining $\mathrm{NO}_{3}^{-}$as the $\mathrm{N}$ source, Coscinodiscus sp. densities declined for all treatments from day 7 to day 12 of the experiment (Figure 4), before returning to initial levels. When competing for $\mathrm{NO}_{3}^{-}$as the $\mathrm{N}$ source, Coscinodiscus sp. densities were not significantly impacted by changes in either $\mathrm{NO}_{3}^{-} \quad(P=0.63)$ or Si concentration $(P=0.77)$. However, the numbers of $T$. rotula were significantly impacted by changes in $\mathrm{NO}_{3}^{-}$concentration ( $P=0.001$, Figure 4). Post-hoc tests showed that cell densities in the zero $\mathrm{NO}_{3}^{-}$treatments were not significantly different to those observed in the $605 \mu \mathrm{M}$ $\mathrm{NO}_{3}^{-}$treatments $(P=0.99)$, but were significantly lower than the cell densities in the $1210 \mu \mathrm{M} \mathrm{NO} \mathrm{NO}_{3}^{-}$treatments $(P=0.001)$. Cell densities in the $605 \mu \mathrm{M} \mathrm{NO}-$ treatment were significantly lower than densities observed in the $1210 \mu \mathrm{M} \mathrm{NO} \mathrm{NO}_{3}^{-}$treatments $(P=0.001)$. Changes in Si concentration had no significant effect on $T$. rotula cell densities ( $P=0.97$; Table 3). Interactions between $\mathrm{NO}_{3}^{-}$and Si were not observed for Coscinodiscus sp. ( $P$ $=0.84)$ or $T$. rotula $(P=0.41$; Table 3$)$.

\section{Discussion}

\subsection{Single Species Responses to Changes in $\mathbf{N}$ and $\mathrm{Si}$ Levels}

In monoculture, the impact of $\mathrm{NH}_{4}-\mathrm{N}$ on algal abundance was size dependent. The increase of $\mathrm{NH}_{4}-\mathrm{N}$ concentra- 
tion significantly enhanced the abundance of the large species, but did not significantly affect the small species. While still able to survive initially in $\mathrm{NH}_{4}^{+}$, both Coscinodiscus sp. and T. rotula did not increase in abundance over the duration of the experiment when $\mathrm{NH}_{4}^{+}$was the $\mathrm{N}$ source. Indeed, the $T$. rotula density decreased over the experimental period. Since $\mathrm{NH}_{4}^{+}$is difficult to store, and is assimilated more quickly than it can be taken up [15], cells of both Coscinodiscus sp. and T. rotula may not be able to satisfy $\mathrm{N}$ requirements with $\mathrm{NH}_{4}^{+}$alone. Coscinodiscus sp. was significantly affected by changes in $\mathrm{NH}_{4}^{+}$concentration, with cell densities in the nil $\mathrm{NH}_{4}^{+}$ treatment lower than those in the other treatments, and no difference in cell density between the $28 \mu \mathrm{M}$ and $56 \mu \mathrm{M}$ $\mathrm{NH}_{4}^{+}$treatments. At zero $\mathrm{NH}_{4}^{+}$, no $\mathrm{N}$ can be gained from the medium, and cells must rely on $\mathrm{N}$ stores to ensure their survival. This would result in slow cell division as algal cells usually reduce reproduction to reduce metabolism of stored $\mathrm{N}$ when the ambient nutrients are low [18]. Thalassiosira rotula was not significantly affected by changes in $\mathrm{NH}_{4}^{+}$concentration, but cell densities decreased over the experimental period when $\mathrm{NH}_{4}^{+}$was the $\mathrm{N}$ source, a phenomenon observed previously in other diatoms by Stolte et al. [15]. This decrease may be due to the exhaustion of supplies of stored $\mathrm{N}$ in the smaller $T$. rotula cells.

Compared with $\mathrm{NH}_{4}-\mathrm{N}, \mathrm{NO}_{3}-\mathrm{N}$ concentration significantly enhanced the small species, but not the large species. When $\mathrm{NO}_{3}^{-}$was used as the $\mathrm{N}$ source, there was no change in Coscinodiscus sp. cell densities over the duration of the experiment, even in the zero $\mathrm{NO}_{3}^{-}$concentration, which suggests that Coscinodiscus sp. is still able to survive on stored $\mathrm{N}$ after three weeks without an $\mathrm{N}$ supply. Sommer [19] reported that in times of $\mathrm{N}$ shortage, algal cells could utilize stored $\mathrm{N}$ to sustain survival. In the present study, the absence of a significant difference in cell densities between the $0 \mu \mathrm{M} \mathrm{NO}_{3}^{-}$and $1210 \mu \mathrm{M}$ $\mathrm{NO}_{3}^{-}$concentrations suggests that total $\mathrm{N}$ stores had not yet reduced to a level in Coscinodiscus sp. cells where a slowing of metabolism was necessary. In contrast to Coscinodiscus sp., $T$. rotula densities were significantly affected by changes in $\mathrm{NO}_{3}^{-}$concentration. The cell densities of $T$. rotula in the zero $\mathrm{NO}_{3}^{-}$level were significantly lower than densities in $1210 \mu \mathrm{M} \mathrm{NO} \mathrm{NO}_{3}^{-}$, but cell densities did not significantly decrease over the course of the experiment, suggesting that a reduction in cell metabolism and division may be a strategy for algal cells to adapt to low N [20]. By slowing metabolism when no N is available in the culture medium, cells of $T$. rotula may be able to prolong survival by using stored $\mathrm{NO}_{3}^{-}$[18]. The resulting reduction in cell division may account for the significantly lower cell densities in zero $\mathrm{NO}_{3}^{-}$when compared to $1210 \mu \mathrm{M} \quad \mathrm{NO}_{3}^{-}$.

A change in Si concentration had no significant effect on cell densities of either Coscinodiscus sp. or T. rotula when $\mathrm{NH}_{4}^{+}$was the $\mathrm{N}$ source. When grown in $\mathrm{NO}_{3}^{-}$the cells did not appear to be limited by the $142 \mu \mathrm{M}$ Si treatment, since densities were not significantly different to those observed in the $562 \mu \mathrm{M}$ Si treatment. However, cell densities of Coscinodiscus sp. were significantly lower in the absence of a Si supply. The cells were unable to get any Si from the medium when the Si concentration was zero, thus conditions were not suitable for regular growth, and cell densities were significantly lower than treatments where $\mathrm{Si}$ was available. However, when grown in $\mathrm{NO}_{3}^{-}$without $\mathrm{Si}$, Coscinodiscus sp. cell densities did not decrease over the duration of the experiment. There are two possible explanations for this result. Firstly, the cells could redirect Si usage to ensure their survival in the shortage of Si supply [21]. In addition to its requirement for frustule formation, diatoms need $\mathrm{Si}$ for DNA, protein and chlorophyll synthesis, and the production of thymidilate kinase and DNA-polymerase [13]. Without sufficient Si for these necessities, normal cellular function would cease. The survival strategies to limited Si supplies include changes in frustule valve morphology [22] and frustule thickness [23]. These responses require less $\mathrm{Si}$ for frustule formation, which leaves it available for other cellular requirements, thereby prolonging the life of the cell. In this study, however, no Si was available in the zero Si treatment. For Coscinodiscus sp. cells to survive in the environment without an external $\mathrm{Si}$ supply they might obtain Si from internal storage. Binder and Chisholm [13] reported the internal formation of Si pools in Si limited diatom populations, which could prolong the life of the cell if coupled with a slowing of the cell cycle. However, prior to exposure to the Si concentrations in this study, Coscinodiscus sp. cells were not $\mathrm{Si}$ limited, and thus any Si stored before the experiment was not stored as a survival response. The second possible explanation involves bacterial digestion of the frustule. Bidle and Azam [24] suggested that bacterially mediated Si regeneration could be achieved via the hastening of diatom frustule dissolution by marine bacteria. Thus it may be possible for diatoms to obtain a Si supply through bacterially mediated recycling in the absence of $\mathrm{Si}$ in the environment. A decrease in Coscinodiscus sp. densities was observed in all $\mathrm{NO}_{3}^{-}$concentrations on the third day of the $\mathrm{NO}_{3}^{-}$monoculture experiment. The dead cells resulting from this decrease might have provided a Si supply for the remaining Coscinodiscus sp. population if bacteria present in the non-axenic cultures were accelerating the dissolution of the unoccupied frustules. Thalassiosira rotula densities were also affected by changing $\mathrm{Si}$ concentrations in the $\mathrm{NO}_{3}^{-}$medium. However, in contrast to Coscinodiscus sp., the effect of Si limitation was found in 0 and $142 \mu \mathrm{M}$ Si treatments. This result may be explained by the size of $T$. rotula relative to Coscinodis- 
cus sp. The smaller $T$. rotula may have less Si available for regeneration in the form of changing frustule morphology and thickness, thereby becoming Si deficient more quickly than Coscinodiscus sp.

\subsection{Nutrient Competition between Two Algal Species}

In the competition experiment between Coscinodiscus sp. and $T$. rotula for $\mathrm{N}$, the large species was dominant over the small one in both $\mathrm{N}$ forms when nutrients were limiting. In $\mathrm{NH}_{4}^{+}$medium, Coscinodiscus sp. dominated by the end of most treatment combinations. This pattern of dominance showed that small diatom was out competed for nutrients in all treatment levels, except when both $\mathrm{NH}_{4}^{+}$ and $\mathrm{Si}$ were present in maximal levels. In $\mathrm{NO}_{3}^{-}$medium, Coscinodiscus sp. also dominated the assemblage at the end of most treatments. This indicates that small species was unable to compete with large species for $\mathrm{NO}_{3}^{-}$when $\mathrm{NO}_{3}^{-}$concentrations are less than $1210 \mu \mathrm{M} \mathrm{NO}_{3}^{-}$.

The effects of changing $\mathrm{N}$ and $\mathrm{Si}$ on Coscinodiscus sp. densities, when grown in competition with $T$. rotula, were essentially the same as those observed when Coscinodiscus sp. was growing in monoculture. This suggests that $T$. rotula has no effect on the growth of Coscinodiscus sp. in the competition studies. However, the effects of changing nutrient concentrations on $T$. rotula densities, when grown in competition with Coscinodiscus sp., were different from the effects observed when $T$. rotula was grown in $\mathrm{NO}_{3}^{-}$and $\mathrm{NH}_{4}^{+}$in monoculture. When grown with $\mathrm{NH}_{4}^{+}-\mathrm{N}, T$. rotula abundances were significantly affected by changes in $\mathrm{NH}_{4}^{+}$and $\mathrm{Si}$ concentration in the competition study. These effects were not observed when $T$. rotula was growing by itself. When grown in $\mathrm{NH}_{4}^{+}$in monoculture, $T$. rotula densities began to decrease between day 8 and day 13 of the study. When competing with Coscinodiscus sp. for $\mathrm{NH}_{4}^{+}$, this decrease occurred more quickly, between day 3 and day 13 of the experiment. Similar results were observed when comparing monoculture and competition studies for cells growing in $\mathrm{NO}_{3}^{-}-\mathrm{N}$. These findings suggest that the large species is a stronger competitor for $\mathrm{N}$ and can out compete the small species.

Ammonia $\left(\mathrm{NH}_{4}^{+}\right)$is a positively charged or neutral $\left(\mathrm{NH}_{3}\right)$ molecule, and can therefore easily diffuse over biological membranes, making it difficult to store [9]. In $\mathrm{NH}_{4}^{+}$medium, the competitive superiority of Coscinodiscus sp. may be due to a higher $\mathrm{NH}_{4}^{+}$uptake rate (i.e. a higher affinity for $\mathrm{NH}_{4}^{+}$), because assimilation of $\mathrm{NH}_{4}^{+}$ is a faster process and nitrogen is more rapidly incorporated into amino acids than it is taken up at the cell surface [14]. In $\mathrm{NO}_{3}^{-}$medium, dominance of Coscinodiscus sp was probably due to its large size, which enables to store a greater amount of $\mathrm{NO}_{3}^{-}$in a larger vacuole [15]. Stored $\mathrm{NO}_{3}^{-}$can be utilized when $\mathrm{NO}_{3}^{-}$levels are low, which allows the cell to survive when sufficient $\mathrm{N}$ cannot be taken up from the medium. This advantage allowed Coscinodiscus sp. to more efficiently make use of the available nutrients when $\mathrm{NO}_{3}^{-}$was the $\mathrm{N}$ source, and thus dominate the community. These results agree with previous studies, which have reported the dominance of larger diatoms when $\mathrm{NO}_{3}^{-}$is the sole $\mathrm{N}$ source [14].

Results from the monoculture experiments showed that both Coscinodiscus sp. and T. rotula were unable to satisfy $\mathrm{N}$ requirements with $\mathrm{NH}_{4}^{+}$alone, and probably used whatever $\mathrm{NH}_{4}^{+}$they could take up from the medium together with stored $\mathrm{NO}_{3}^{-}$to ensure $\mathrm{N}$ requirements were met. A higher affinity for $\mathrm{NH}_{4}^{+}$uptake, together with a large capacity for $\mathrm{NO}_{3}^{-}$storage, might have provided Coscinodiscus sp. with a competitive advantage when $\mathrm{NH}_{4}^{+}-\mathrm{N}$ was the $\mathrm{N}$ source in this study, by enabling the cells to more efficiently make use of total available $\mathrm{N}$ (i.e., stored $\mathrm{NO}_{3}^{-}$, and $\mathrm{NH}_{4}^{+}$in the culture medium). The disadvantaged $T$. rotula, with a smaller storage capacity were possibly unable to secure a sufficient $\mathrm{N}$ supply when $\mathrm{NH}_{4}^{+}-\mathrm{N}$ was the $\mathrm{N}$ source. As stored $\mathrm{NO}_{3}^{-}$was used up, T. rotula were unable to survive on $\mathrm{NH}_{4}^{+}$alone and cell densities decreased as the experiment progressed. This result was more pronounced in the lower Si concentrations, which may imply that cells that are unable to obtain a sufficient $\mathrm{N}$ supply are less competitive for low $\mathrm{Si}$ levels. If $\mathrm{N}$ supplies were insufficient, cells may prioritize their $\mathrm{N}$ requirements, addressing the needs of cellular functions essential to survival first. The selective loss of non-essential $\mathrm{N}$ compounds in response to $\mathrm{N}$ deficiency, including the reduction of cellular protein content has been reported in a previous study on marine diatoms [18]. This loss might include the proteins required for the completion of Si metabolism [12]. This may explain why cells that were unable to acquire an adequate supply of $\mathrm{N}$ might have been prevented from meeting their Si requirements via an incomplete Si transport system.

When $\mathrm{NH}_{4}^{+}-\mathrm{N}$ was the $\mathrm{N}$ source, $T$. rotula was out competed for $\mathrm{NH}_{4}^{+}$, and was therefore out competed for $\mathrm{Si}$. When $\mathrm{NO}_{3}^{-}-\mathrm{N}$ was the $\mathrm{N}$ source, $T$. rotula was outcompeted for $\mathrm{NO}_{3}^{-}$, and was therefore out-competed for $\mathrm{Si}$. These results provide evidence for the key dilemmas outlined in the introduction. Firstly, we show that competition for $\mathrm{Si}$ is $\mathrm{N}$ source dependent, since in both $\mathrm{NH}_{4}^{+}$ and $\mathrm{NO}_{3}^{-}$, the species that was best able to utilize the $\mathrm{N}$ source dominated the assemblage. Secondly, we have demonstrated that competition for $\mathrm{N}$ is dependent on $\mathrm{N}$ source in the environment, with large species dominating in $\mathrm{NO}_{3}^{-}$, and the species with the highest affinity for the nutrient dominating in $\mathrm{NH}_{4}^{+}$. The larger Coscinodiscus sp. dominated when $\mathrm{NO}_{3}^{-}-\mathrm{N}$ was the $\mathrm{N}$ source, and the species with the highest affinity for $\mathrm{NH}_{4}^{+}$, also Coscinodiscus sp., dominated when $\mathrm{NH}_{4}^{+}-\mathrm{N}$ was the $\mathrm{N}$ source. However, it should be noted that the affinity of Coscino- 
discus sp and T. rotula for a particular nitrogen source was not directly examined in this study. A comparison of uptake rates and $\mathrm{K}_{\mathrm{s}}$ values for the different forms of nitrogen would provide further valuable information on the nature of competition between these two species.

\section{Acknowledgements}

We thank Sandra Marshall for assistance with algal culture, and Kylie Lange for her help with statistical analysis.

\section{REFERENCES}

[1] G. E. Hutchinson, "The Paradox of the Plankton,” American Naturalist, Vol. 95, No. 882, 1961, pp. 137-145. doi:10.1086/282171

[2] D. A. Siegel, "Resource Competiton in a Discrete Environment: Why Are Phytoplankton Distributions Paradoxical?” Limnology and Oceanography, Vol. 43, No. 6, 1998, pp. 113-146. doi:10.4319/lo.1998.43.6.1133

[3] D. Tilman, "Resource Competition between Planktonic Algae: An Experimental and Theoretical Approach,” Ecology, Vol. 58, No. 26, 1977, pp. 338-348. doi: $10.2307 / 1935608$

[4] U. Sommer, "Are Marine Diatoms Favoured by High Si:N Ratios?” Marine Ecology Progress Series, Vol. 115, 1994, pp. 309-315. doi:10.3354/meps115309

[5] W. Stolte and R. Riegman, “A Model Approach for SizeSelective Competition of Marine Phytoplankton for Fluctuating Nitrate and Ammonium," Journal of Phycology, Vol. 32, No. 5, 1996, pp. 732-740.

doi:10.1111/j.0022-3646.1996.00732.x

[6] J. K. Egge and D. L. Aksnes, "Silicate as Regulating Nutrient in Phytoplankton Competition," Marine Ecology Progress Series, Vol. 83, 1992, pp. 281-289. doi:10.3354/meps083281

[7] C. W. Sullivan, "Diatom Mineralization of Silicic Acid 1. $\mathrm{Si}(\mathrm{OH})_{4}$ Transport Characteristics in Navicula pelliculosa," Journal of Phycology, Vol. 12, No. 4, 1976, pp. 390-396.

[8] M. A. Brzezinski, R. J. Olson and S. W. Chisholm, "Silicon Availability and Cell Cycle Progression in Marine Diatoms," Marine Ecology Progress Series, Vol. 67, 1990, pp. 83-96. doi:10.3354/meps067083

[9] T. A. Probyn, "Nitrogen Uptake by Size Fractionated Phytoplankton Populations in the Southern Benguela Upwelling System,” Marine Ecology Progress Series, Vol. 22, 1985, pp. 249-258. doi:10.3354/meps022249

[10] M. W. Lomas and P. M. Gilbert, "Interactions between Nitrate and Ammonium Uptake and Assimialtion: Comparison of Diatoms and Dinoflagellates at Different Growth Temperatures,” Marine Biology, Vol. 133, No. 3, 1999, pp. 541-551. doi:10.1007/s002270050494

[11] M. A. Brzezinski, "Cell Cycle Effects on the Kinetics of Silicic Acid Uptake and Resource Competition among Diatoms," Journal of Plankton Research, Vol. 14, No.
114, 1992, pp. 1511-1539. doi:10.1093/plankt/14.11.1511

[12] M. A. Brzezinski and D. J. Conley, "Silicon Deposition during the Cell Cycle of Thalassiosira weisfloggi (Bacillariophyceae) Determined Using Dual Rhodamine123 and Propidium Iodide Staining,” Journal of Phycology, Vol. 30, No. 1, 1994, pp. 45-55. doi:10.1111/j.0022-3646.1994.00045.x

[13] B. J. Binder and S. W. Chisholm, "Changes in the Soluble Silicon Pool Size in the Marine Diatom Thalassiosira weisfloggi," Marine Biology Letters, Vol. 1, 1980, pp. 205-212.

[14] W. Stolte and R. Riegman, "Effect of Phytoplankton Cell Size on Transient State Nitrate and Ammonium Uptake Kinetics,” Microbiology, Vol. 141, No. 5, 1995, pp. 12211229. doi:10.1099/13500872-141-5-1221

[15] W. Stolte, T. McCollin, A. A. M. Noordeloos and R. Riegman, "Effect of Nitrogen Source on the Size Distribution within Phytoplankton Populations,” Journal of Experimental Marine Biology and Ecology, Vol. 184, No. 1, 1994, pp. 83-97. doi:10.1016/0022-0981(94)90167-8

[16] R. R. L. Guillard and J. H. Ryther, "Studies on Marine Diatoms 1. Cyclotella Nana and Hustedt and Detonula Confervacea Gran,” Canadian Journal of Microbiology, Vol. 8, No. 2, 1962, pp. 229-239. doi:10.1139/m62-029

[17] P. Diggle, “Analysis of Longitudinal Data,” Clarendon Press, Oxford, 1994.

[18] Q. Dortch, "Effect of Growth Conditions on Accumulation of Internal Nitrate, Ammonium Amino Acids and Protein in Three Marine Diatoms," Journal of Experimental Marine Biology and Ecology, Vol. 61, No. 3, 1982, pp. 243-264. doi:10.1016/0022-0981(82)90072-7

[19] U. Sommer, "Nitrate and Silicate Competition among Antarctic Phytoplankton,” Marine Biology, Vol. 91, No. 31, 1986, pp. 345-351. doi:10.1007/BF00428628

[20] W. G. Harrison, L. R. Harris and B. D. Irwin, "The Kinetics of Nitrogen Utilization in the Oceanic Mixed Layer: Nitate and Ammonuim Interactions at Nanomolar Concentrations," Limnology and Oceanography, Vol. 41, No. 1, 1996, pp. 16-32. doi:10.4319/lo.1996.41.1.0016

[21] C. W. Sullivan, "Diatom Mineralization of Silicic Acid 2. Regulation of $\mathrm{Si}(\mathrm{OH})_{4}$ Transport Rates during the Cell Cycle of Navicula pelliculosa," Journal of Phycology, Vol. 13, 1977, pp. 86-91.

[22] B. Booth and P. J. Harrison, "Effect of Silicate Limitation on Valve Morphology in Thalassiosira and Coscinodiscus sp. (Bacillariophyceae)," Journal of Phycology, Vol. 15, No. 3, 1979, pp. 326-329. doi:10.1111/j.1529-8817.1979.tb02647.x

[23] E. Paasche, "Silicon and the Ecology of Marine Planktonic Diatoms 1. Thalassiosira pseudonana (Cyclotella nana) Grown in Chemostat with Silicate as Limiting Nutrient,” Marine Biology, Vol. 19, No. 2, 1973, pp. 117126. doi:10.1007/BF00353582

[24] K. D. Bidle and F. Azam, "Accelerated Dissolution of Diatom Silica by Marine Bacterial Assemblages,” Nature, Vol. 397, 1999, pp. 508-512. doi:10.1038/17351 